\title{
ZGODA NA PRZEPROWADZENIE PROCEDURY MEDYCZNIE WSPOMAGANEJ PROKREACJI A WOLNOŚĆ PROKREACYJNA MĘŻCZYZNY W ŚWIETLE USTAWY O LECZENIU NIEPŁODNOŚCI
}

\begin{abstract}
Abstrakt: Przedmiotem artykułu jest analiza zagadnienia zgody mężczyzny będącego uczestnikiem medycznie wspomaganej prokreacji na jej przeprowadzenie oraz jej skutków rodzinnoprawnych, a także następstwa jej nieudzielenia lub odwołania w kontekście jego swobody prokreacyjnej. Obowiązująca w tym zakresie regulacja prawna wzbudza wątpliwości interpretacyjne dotyczące równego statusu uczestników procedury medycznie wspomaganej prokreacji oraz pozycji prawnej mężczyzny w zależności od tego, czy jest on małżonkiem, czy partnerem biorczyni oraz od tego, czy para poddaje się omawianemu zabiegowi w ramach dawstwa partnerskiego czy dawstwa innego niż partnerskie.
\end{abstract}

Słowa kluczowe: prokreacja, procedura, niepłodność, zgoda, ojcostwo

\section{WPROWADZENIE}

Procedury medyczne leczenia niepłodności zostały uregulowane ustawą z dnia 25 czerwca 2015 roku o leczeniu niepłodności ${ }^{1}$. Zgodnie z podmiotowymi warunkami dostępu do omawianych procedur może z nich skorzystać jedynie para pełnoletnich, posiadających zdolność do czynności prawnych małżonków lub partnerów odmiennej płci pozostających we wspólnym pożyciu, które zostało potwierdzone zgodnym oświadczeniem ${ }^{2}$. W związku z powyższym, mimo że procedury medyczne związane z leczeniem niepłodności podejmowane są bezpośrednio wobec kobiety, udział mężczyzny będącego jej małżonkiem lub partnerem jest warunkiem koniecznym. Nadaje to szczególnego znaczenia oświadczeniu mężczyzny, na podstawie którego przeprowadza się zabieg medycznie wspomaganej prokreacji.

${ }^{1}$ Dz.U. z 2020 r. poz. 442; dalej: u.1.n.

2 Por. art. 2 ust. 1 pkt 8 u.l.n. 
Z punktu widzenia dalszych rozważań kluczowe znaczenie ma przyjęcie przez ustawodawcę dopuszczalności przeprowadzenia procedury medycznie wspomaganej prokreacji: $\mathrm{w}$ ramach dawstwa partnerskiego albo dawstwa innego niż partnerskie. Pojęcie dawstwa partnerskiego zawarte w art. 2 ust. 1 pkt 8 u.l.n. opiera się na przesłankach podmiotowych. Ustawodawca wskazuje bowiem wprost w treści przepisu, że dawstwo to polega na przekazaniu przez dawcę-mężczyznę komórek rozrodczych $\mathrm{w}$ celu zastosowania ich w procedurze medycznie wspomaganej prokreacji u biorczyni, która pozostaje $\mathrm{z}$ dawcą $\mathrm{w}$ związku małżeńskim albo wspólnym pożyciu potwierdzonym zgodnymi oświadczeniami obojga. Drugi $\mathrm{z}$ dopuszczonych przez ustawodawcę wariantów przeprowadzenia zabiegu medycznie wspomaganej prokreacji — dawstwo inne niż partnerskie - nie został zdefiniowany w przepisach ustawy. Zgodnie $\mathrm{z}$ treścią Uzasadnienia do projektu ustawy odnosi się on do sytuacji, w których przynajmniej jedna $z$ komórek rozrodczych wykorzystanych do przeprowadzenia procedury pochodzi od anonimowego dawcy ${ }^{3}$.

Przyjęty przez ustawodawcę sposób uregulowania dostępu do procedur medycznie wspomaganego rozrodu z punktu widzenia swobody prokreacyjnej mężczyzny skutkuje wystąpieniem wątpliwości interpretacyjnych dotyczących zgody mężczyzny na przeprowadzenie omawianej procedury, skutków jej odwołania oraz nieudzielenia.

\section{POJĘCIE WOLNOŚCI PROKREACYJNEJ}

Na wstępie wyjaśnienia wymaga pojęcie wolności prokreacyjnej. Nie stanowi ono terminu należącego do języka prawnego. W literaturze wolność (autonomia) prokreacyjna definiowana jest jako swoboda podejmowania decyzji o posiadaniu lub nieposiadaniu dziecka oraz możliwość decydowania o własnych zdolnościach rozrodczych ${ }^{4}$. W ujęciu negatywnym wolność prokreacyjna oznacza ,prawo-roszczenie" o nieingerowanie podmiotów zewnętrznych w decyzje reprodukcyjne określonej osoby ${ }^{5}$. Nie ulega wątpliwości, że zagadnienie to odgrywa szczególną rolę w kontekście podejmowania medycznych interwencji zmierzających do pozyskania ciąży ${ }^{6}$. Ustawa o leczeniu niepłodności dotyczy również kwestii realizo-

3 Druk sejmowy nr 3245 — Uzasadnienie do projektu ustawy, http://www.sejm.gov.pl/Sejm7. nsf/druk.xsp?nr=3245 (dostęp: 2.02.2020).

4 B. Oszkinis, Wolność prokreacyjna - zarys problematyki, „Prawo i Medycyna” 2013, nr.1-2, s. 161 .

5 J.A. Robertson, Procreative Liberty in the Era of Genomics, „American Journal of Law and Medicine" 2003, nr 29.

${ }^{6}$ W literaturze zwraca się uwagę na fakt, że na gruncie obecnie dostępnych technik medycznego wspomagania rozrodu wybory prokreacyjne mogą mieć znacznie szerszy zakres i dotyczyć nie tylko tego, czy i z kim mieć potomstwo, ale także tego, w jaki sposób i jakie dzieci, na przykład 
wania wolności prokreacyjnej przez osoby dotknięte niepłodnością, ograniczając tę swobodę w wielu aspektach.

Pojęcie wolności prokreacyjnej pozostaje w ścisłym związku z pojęciem rodzicielstwa, które w nowszej literaturze ujmowane jest w kategoriach dobra osobistego polegającego na prawie do bycia rodzicem określonego dziecka ${ }^{7}$. Istotnym aspektem stanowiska traktującego rodzicielstwo jako dobro osobiste jest przyjęcie, że może ono być odnoszone już do dziecka poczętego ${ }^{8}$. Niewątpliwie uwzględnić należy w tym wypadku fakt, że na wcześniejszym etapie, w którym realizowana ma być wola posiadania dziecka, występuje element ewentualności, z którym wiąże się stan niepewności co do ostatecznego rezultatu9 . W kontekście omawianego zagadnienia etap poprzedzający poczęcie dziecka ma istotne znaczenie zwłaszcza w sytuacjach, w których przyszli rodzice zamierzają skorzystać z medycznego wsparcia prokreacji. Złożone wówczas przez nich oświadczenia o wyrażeniu zgody na podjęcie takich zabiegów czy też pobranie w tym celu komórek rozrodczych wpływają na szeroko pojętą swobodę decyzji o posiadaniu potomstwa. Aspekt ten zyskuje szczególnie na znaczeniu w sytuacjach, kiedy upływ czasu między pobraniem komórek rozrodczych a przeprowadzeniem zabiegu medycznie wspomaganej prokreacji, może wpłynąć na zmianę planów prokreacyjnych pacjentów. Wszystko to może rzutować na ustalenie stosunków filiacyjnych w przyszłości.

\section{ZGODA MĘŻA/PARTNERA BIORCZYNI NA PROCEDURĘ MEDYCZNIE WSPOMAGANEJ PROKREACJI}

Szczególne znaczenie dla kwestii wolności prokreacyjnej mężczyzny, którego żona lub partnerka poddaje się zabiegowi medycznie wspomaganej prokreacji, ma jego zgoda na przeprowadzenie tego zabiegu. Znaczenie omawianego oświadczenia ma charakter złożony: $\mathrm{z}$ jednej strony zgoda stanowi przesłankę dopuszczalności przeprowadzenia zabiegu medycznie wspomaganej prokreacji, z drugiej — odnosi się do kwestii ustalenia pochodzenia dziecka od mężczyzny. Podstawą regulacji zgody mężczyzny na przeprowadzenie transferu zarodków lub

biologicznie spokrewnione lub nie. Por. M. Soniewska, Selekcja genetyczna w prokreacji medycznie wspomaganej. Etyczne i prawne kryteria, Warszawa 2018, s. 78 n.

${ }^{7}$ K. Michałowska, Niemajątkowe wartości życia rodzinnego $w$ polskim prawie cywilnym, Warszawa 2017, s. 335.

8 Ibidem, s. 335.

9 M. Łączkowska określa ten stan „potencjalnością”; por. eadem, Czy istnieje prawo do „posiadania" dziecka?, [w:] Prawne, medyczne, psychologiczne aspekty wspomaganej prokreacji, red. J. Haberko, M. Łączkowska, Poznań 2005. 
komórek rozrodczych jest ustawa o leczeniu niepłodności, zaś rodzinnoprawne konsekwencje jej udzielenia reguluje Kodeks rodzinny i opiekuńczy ${ }^{10}$.

Warunki transferu do organizmu biorczyni zarodków powstałych z komórek rozrodczych pobranych w celu dawstwa partnerskiego, albo dawstwa innego niż partnerskie oraz zarodków przekazanych w celu dawstwa, zostały określone w art. 20 u.l.n. W przypadku dawstwa partnerskiego ustawa w art. 20 ust. 1 pkt 1 wymaga wyrażenia pisemnej zgody biorczyni i dawcy, a w przypadku dawstwa innego niż partnerskie — biorczyni i jej męża lub mężczyzny, z którym pozostaje ona we wspólnym pożyciu. Partner biorczyni zobowiązany jest wówczas złożyć oświadczenie, o którym mowa w przepisie art. $75^{1}$ k.r.o. odnoszącym się do uznania ojcostwa dziecka, które urodzi się w następstwie procedury medycznie wspomaganej prokreacji. Należy w tym miejscu zwrócić uwagę na fakt, że w przypadku dawstwa anonimowego wobec mężczyzny niebędącego mężem biorczyni nie przewidziano obowiązku wyrażenia zgody na transfer zarodka. Zamiast tego ma on złożyć oświadczenie o uznaniu ojcostwa odnoszące się do dziecka, które może urodzić się na skutek tego zabiegu. Rozwiązanie to traktowane jest jako nietrafne, ponieważ wyłącza mężczyznę z zakresu decyzyjnego na etapie procedury medycznej ${ }^{11}$.

Również przekazanie zarodka w ramach jego dawstwa wymaga pisemnej zgody dawców komórek rozrodczych, z których powstał zarodek (art. 20 ust. 1 pkt 3 u.l.n.). Jednocześnie ustawodawca nie wypowiedział się w kwestii zgody biorczyni zarodka pochodzącego z dawstwa jej męża lub partnera. W doktrynie przyjmuje się, że jest to efekt zastosowania przez ustawodawcę skrótu myślowego, a biorczyni i jej mąż bądź konkubent nie zostali zwolnieni z obowiązku wyrażenia zgody na przeprowadzenie tego zabiegu ${ }^{12}$.

Należy w tym miejscu podzielić pogląd wyrażony przez J. Haberkę, że zakres podmiotowy zgody na przeniesienie zarodka określony w przepisie art. 20 ust. 1 pkt 1-3 u.l.n. jest nieprecyzyjny ${ }^{13}$. Niejasna jest zwłaszcza ta część regulacji, która odnosi się do zgody wyrażonej przez mężczyznę. Jeśli zgoda pochodzi od męża biorczyni, to pociąga za sobą również istotny skutek w zakresie niedopuszczalności zaprzeczenia ojcostwa, jeśli dziecko urodziło się w następstwie tego zabiegu. Stanowi o tym przepis art. 68 k.r.o. ${ }^{14}$, który w swojej literalnej treści odnosi się

${ }^{10}$ Ustawa z dnia 25 lutego 1964 roku — Kodeks rodzinny i opiekuńczy, Dz.U. nr 9, poz. 59; dalej: k.r.o.

11 J. Haberko, Ustawa o leczeniu nieptodności Komentarz, Warszawa 2016, s. 140.

12 Ibidem, s. 141.

13 Ibidem, s. 140.

14 Należy zwrócić uwagę na fakt, że przepis art. 68 k.r.o. został zmieniony w związku z wejściem w życie u.l.n. W swoim pierwotnym brzmieniu, to jest przed 1 listopada 2015 roku, przepis uznawał zaprzeczenie ojcostwa za niedopuszczalne, jeśli dziecko zostało poczęte na skutek medycznie wspomaganej prokreacji. W znowelizowanym brzmieniu niedopuszczalność ta dotyczy dziecka, które urodziło się w rezultacie zabiegu medycznie wspomaganej prokreacji. Zmiana kwalifikacji czasowej z „,poczęcia” na „urodzenie” ma doniosłe skutki na gruncie filiacyjnym i powinna być 
jedynie do zgody wyrażonej przez męża matki dziecka, nie wspominając jednakże o zgodzie wyrażonej przez mężczyznę pozostającego z nią w stałym pożyciu. Zgoda, o której mowa w tym przepisie, odnoszona może być zatem wyłącznie do zabiegów przeprowadzanych w ramach dawstwa innego niż partnerskie, a zatem wtedy, gdy mąż matki nie jest dawcą męskich komórek rozrodczych.

Uwagę zwraca również fakt, że zgoda mężczyzny, o której mowa w ustawie, nie odnosi się do rozpoczęcia procedury medycznie wspomaganej prokreacji, a tylko do dalszego jej etapu, jakim jest transfer istniejącego już zarodka albo komórek rozrodczych anonimowego dawcy. Należy podzielić stanowisko, zgodnie z którym zgoda ta powinna obejmować wcześniejszy etap i być wyrażona na piśmie, a także poprzedzona informacjami o jej konsekwencjach rodzinnoprawnych ${ }^{15}$.

Doniosłość skutków prawnych wyrażonej przez mężczyznę zgody na transfer zarodka albo komórek rozrodczych anonimowego dawcy widoczna jest zwłaszcza w przyjęciu na siebie obowiązków związanych z rodzicielstwem. Więź prawna ojcostwa powstała na podstawie udzielonej zgody, połączy męża matki z dzieckiem, które nie będzie od niego pochodzić genetycznie. Wobec daleko idących konsekwencji prawnych wyrażonej zgody, można by oczekiwać od ustawodawcy bardziej precyzyjnego uregulowania w tym zakresie.

Wśród postulatów zgłaszanych $\mathrm{w}$ doktrynie na uwagę zasługują również te, które zaprezentowane zostały jeszcze przed wejściem w życie Ustawy o leczeniu niepłodności, ale nie zostały w niej zrealizowane. Wiążą się one z faktem długotrwałości procedur medycznie wspomaganej prokreacji, która powinna przekładać się na obowiązek pozyskiwania zgody nie tylko przy rozpoczęciu procedury, ale także podtrzymywaniu jej w odpowiedniej, mniej sformalizowanej formie na kolejnych etapach trwania procedury medycznej, po otrzymaniu informacji co do stopnia inwazyjności i ryzyka poszczególnych zabiegów ${ }^{16}$.

uznana za wyraz niekonsekwencji ustawodawcy, zwłaszcza w świetle jednoczesnej dopuszczalności uznania ojcostwa od chwili poczęcia dziecka.

15 M. Domański, [w:] Kodeks rodzinny i opiekuńczy. Komentarz. Przepisy wprowadzajace $K R O$, t. 5, red. K. Osajda, Warszawa 2017, s. 981. Obecnie pisemna zgoda męża poprzedzona szczegółowym poinformowaniem go na piśmie o skutkach prawnych stosowania komórek rozrodczych lub zarodka w procedurze medycznie wspomaganej prokreacji, o których mowa w Kodeksie rodzinnym i opiekuńczym, jest wymaga również przepisami art. 31 ust. 2 pkt $6-7$ oraz art. 36 ust. 1 pkt 7 lit. a Ustawy o leczeniu niepłodności. Poza wskazanymi przepisami ustawa nie odnosi się w innych miejscach do kwestii zgody męża biorczyni, co uznawane jest w literaturze za wadę tej regulacji. Tak: M. Domański, op. cit., s. 981

16 J. Haberko, Kilka uwag na temat zgody na zabieg medyczny wyrażonej przez matżonka w trybie art. 68 k.r.o., „,Ruch Prawniczy, Ekonomiczny i Socjologiczny” 2010, z. 1, s. 53. 


\section{RODZINNOPRAWNE SKUTKI UDZIELENIA ZGODY PRZEZ MĘŻA BIORCZYNI}

Rodzinnoprawne konsekwencje udzielenia przez męża zgody na transfer zarodków przewiduje art. 68 Kodeksu rodzinnego i opiekuńczego. Zgodnie z jego treścią nie jest dopuszczalne zaprzeczenie ojcostwa, jeżeli dziecko urodziło się w następstwie procedury medycznie wspomaganej prokreacji, na którą mąż wyraził zgodę. W pierwotnym brzmieniu, to jest przed 1 listopada 2015 roku, przepis za niedopuszczalne uznawał zaprzeczenie ojcostwa, jeśli dziecko zostało poczęte na skutek zabiegu medycznie wspomaganej prokreacji. W efekcie wejścia w życie Ustawy o leczeniu niepłodności dokonano zmiany brzmienia tego przepisu. Obecnie niedopuszczalność ta dotyczy dziecka, które urodziło się w wyniku zabiegu medycznie wspomaganej prokreacji. Wskazuje się, że zmiana ma znaczenie porządkujące i pozwala skorelować regulację zaprzeczenia ojcostwa z ramami czasowymi domniemania pochodzenia dziecka od męża matki, o którym mowa w art. 62 Kodeksie rodzinnym i opiekuńczym ${ }^{17}$. W kwestii dopuszczalności uznania ojcostwa jeszcze przed poczęciem dziecka, dostrzega się w tym uregulowaniu brak konsekwencji ustawodawcy w zakresie uznania podmiotowości prawnej dziecka poczętego ${ }^{18}$.

Zwraca uwagę, że art. 68 k.r.o. odnosi się jedynie do zgody wyrażonej przez męża matki dziecka, nie wspominając o zgodzie wyrażonej przez mężczyznę pozostającego z nią w stałym pożyciu. Zgoda, o której mowa w tym przepisie, odnoszona może być zatem wyłącznie do zabiegów przeprowadzanych w ramach dawstwa innego niż partnerskie, a więc wtedy, gdy mąż matki nie jest dawcą męskich komórek rozrodczych.

\section{ODWOŁANIE I NIEUDZIELENIE ZGODY PRZEZ MĘŻA BIORCZYNI}

Poważne wątpliwości wzbudza również aktualnie obowiązująca regulacja odwołania udzielonej zgody. Ustawodawca przewiduje taką możliwość dla dawców komórek rozrodczych oraz zarodka aż do momentu rozpoczęcia u biorczyni procedury medycznie wspomaganej prokreacji, w której mają być one wykorzystane ${ }^{19}$. Jednocześnie zupełnie pominięto w ustawie kwestię dopuszczalności odwołania zgody udzielonej przez męża biorczyni. Przesłanki niedopuszczalności transferu, o których mowa w art. 21 u.1.n, odnoszą się wprost jedynie do cofnięcia zgody przez biorczynię.

17 Tak: J. Haberko, Ustawa..., s. 409; M. Domański, op. cit., s. 977.

18 J. Haberko, Ustawa..., s. 408-409.

19 Kwestii odwołania zgody przez dawców poświęcono art. 22 pkt 1, art. 29 ust. 2 i 3, art. 30 ust. 2 i 3 oraz art. 36 ust. 4 i 5 u.l.n. 
W odniesieniu do zgody męża mowa wyłącznie o jej nieudzieleniu. Wobec takiego brzmienia omawianego przepisu należy przyjąć, że cofnięcie zgody przez męża biorczyni na zastosowanie u niej komórek rozrodczych anonimowego dawcy albo zarodka pochodzącego z dawstwa zarodka jest niedopuszczalne. Sytuacja taka oznacza poważną dysproporcję między uprawnieniami biorczyni i jej męża, który został pozbawiony możliwości odwołania raz udzielonej zgody.

Brak regulacji dotyczącej odwołania zgody na przeniesienie do organizmu biorczyni komórek rozrodczych anonimowego dawcy albo zarodka pochodzącego z dawstwa czyni aktualnym pytanie o ramy czasowe skuteczności raz udzielonej przez męża zgody.

Ustawodawca wprowadza ograniczenie czasowe jedynie w przypadku oświadczenia o uznaniu ojcostwa składanego na podstawie art. $75^{1}$ k.r.o. — dotyczy ono mężczyzny pozostającego $\mathrm{z}$ biorczynią w stałym pożyciu w przypadku zastosowania u niej komórek rozrodczych anonimowego dawcy lub zarodka utworzonego z komórek rozrodczych niepochodzących od partnera biorczyni. Jest ono o tyle skuteczne, o ile dziecko poczęte na skutek zabiegu medycznie wspomaganej prokreacji urodzi się w ciągu dwóch lat od jego złożenia. Brak jednak w ustawie podobnego uregulowania $\mathrm{w}$ odniesieniu do zgody męża.

Niewątpliwie kwestia ta powinna być przez ustawodawcę uporządkowana, zwłaszcza że sytuacja życiowa małżonków może podlegać zmianom, a konsekwencje prawne zgody na gruncie stosunków filiacyjnych są bardzo daleko idą$\mathrm{ce}^{20}$. W literaturze wyrażane jest stanowisko, zgodnie z którym w obowiązującym stanie prawnym jedynie upływ trzystu dni od ustania, unieważnienia małżeństwa lub orzeczenia separacji, o którym mowa w art. 62 k.r.o., może spowodować uchylenie skutków udzielenia zgody ${ }^{21}$. Zaznaczyć przy tym należy, że okres ten powinien upłynąć przed przeniesieniem do organizmu biorczyni komórek rozrodczych anonimowego dawcy lub przeniesieniem zarodka.

\section{ZASTĘPCZE ZEZWOLENIE SĄDU NA PRZEPROWADZENIE PROCEDURY MEDYCZNIE WSPOMAGANEJ PROKREACJI}

Nieudzielenie zgody przez męża skutkuje brakiem możliwości przeprowadzenia procedury medycznie wspomaganego rozrodu. W tej sytuacji ustawodawca dopuszcza możliwość wyrażenia przez sąd zezwolenia na jej przeprowadzenie, które zastępuje zgodę męża. Zagadnienie to w istotny sposób wpływa na swobodę decyzji mężczyzny w zakresie jego planów prokreacyjnych. Zezwolenie sądu zastępujące zgodę męża może być, zgodnie z treścią art. 21 ust. 1 i 2 u.l.n., zastosowane w przypadku przeniesienia do organizmu biorczyni zarodka powstałego

20 Ibidem.

${ }^{21}$ Ibidem. 
z komórek rozrodczych pobranych w ramach dawstwa partnerskiego lub innego niż partnerskie. Zezwolenie sądu nie może zastąpić zgody męża ani w przypadku transferu zarodka w ramach dawstwa zarodka, ani transferu do organizmu biorczyni komórek rozrodczych anonimowego dawcy.

Formuła zgody sądu zastępującej zgodę męża ma rozstrzygać sytuacje, w których małżonkowie nie mogą osiągnąć porozumienia co do przeniesienia do organizmu żony (biorczyni) wcześniej utworzonego zarodka. Należy jednak zwrócić uwagę na fakt, że po raz kolejny pozycja obojga małżonków nie jest równa. Zastępujące zgodę męża zezwolenie sądu może być wydane wyłącznie na żądanie biorczyni. Jednocześnie małżonek, który chciałby wbrew woli żony kontynuować procedurę medycznie wspomaganej prokreacji, nie został przez ustawodawcę wyposażony w tego rodzaju narzędzie prawne.

Pozytywnie należy ocenić regulację zakazującą kontynuowania procedury medycznej wspomaganej prokreacji bez zgody biorczyni, jednakże wątpliwości wzbudza możliwość jej przeprowadzenia bez zgody męża. W sposób oczywisty czyni to sytuację obojga małżonków nierówną w świetle uregulowań ustawy. Nieprzekonujący wydaje się również argument, że tryb sądowej zgody zastępczej ma charakter „trybu awaryjnego", który może zostać zastosowany w przypadku, gdy po poddaniu się długotrwałemu i obciążającemu leczeniu niepłodności, na skutek którego powstały zarodki nadające się do transferu, małżonek biorczyni odmówił wyrażenia zgody na przeprowadzenie zabiegu ${ }^{22}$. Zgoda sądu wyrażona $\mathrm{w}$ formie postanowienia wydaje się jednocześnie ingerować w najbardziej osobistą sferę stosunków rodzinnych związanych z prokreacją i planowaniem rodziny. Na skutek zastąpienia jego zgody postanowieniem sądu, ojcostwo męża biorczyni jest przymusowo narzucone i może być ocenione jako dyskryminujące go.

Zastępcze zezwolenie sądu dotyczy przeniesienia zarodka lub komórek rozrodczych do organizmu biorczyni, a zatem rzeczywistego przeprowadzenia zabiegu medycznego. Problematyczna jednak pozostaje kwestia możliwości zaprzeczenia ojcostwa męża biorczyni w sytuacji, gdy zamiast niego zezwolenia na transfer udzielił sąd.

Część przedstawicieli doktryny przyjmuje, że zastępcze zezwolenie sądu nie tylko legalizuje zabieg medycznie wspomaganej prokreacji, lecz także wywołuje wobec męża biorczyni skutki przewidziane w art. 68 Kodeksu rodzinnego i opiekuńczego ${ }^{23}$. Podnosi się jednocześnie, że przepis w tym kształcie nie może być akceptowany, ponieważ prowadzi do powstania ojcostwa niezgodnego z intencją dawcy, które ma charakter przymusowy ${ }^{24}$. Takie unormowanie oceniane jest ne-

22 M. Domański, op. cit., s. 983.

${ }^{23}$ K. Bączyk-Rozwadowska, Prokreacja medycznie wspomagana. Studium z dziedziny prawa, Toruń 2018, s. 685-686; J. Haberko, Ustawa..., s. 151.

${ }^{24}$ K. Bączyk-Rozwadowska, op. cit., s. 686. 
gatywnie jako nieuwzględniające innych respektowanych przez system prawny wartości, które skutkują w obszarze relacji prawnorodzinnych ${ }^{25}$.

Zgodnie z drugim zapatrywaniem zgoda sądu nie zastępuje zgody wyrażonej przez męża i nie może skutkować „,definitywnym przypisaniem ojcostwa mężowi" ${ }^{26}$. Należy przez to rozumieć, że zezwolenie wydane przez sąd w formie postanowienia nie zastępuje zgody, o której mowa w art. 68 Kodeksu rodzinnego i opiekuńczego. W sytuacji ustania małżeństwa, jego unieważnienia albo orzeczenia separacji po uprawomocnieniu się postanowienia sądu o udzieleniu zgody, ze względu na brak ograniczeń czasowych jej skuteczności, możliwy byłby transfer zarodka do organizmu biorczyni. Jednocześnie urodzenie się dziecka po upływie trzystu dni od ustania małżeństwa, unieważnienia albo orzeczenia separacji skutkowałoby tym, że ojcostwo męża biorczyni nie zostanie ustalone, a przepis art. 68 k.r.o. w ogóle nie znajdzie zastosowania. Przyjęcie, że postanowienie sądu w efekcie nie skutkuje przypisaniem ojcostwa, a jedynie pozwala na przeprowadzenie zabiegu medycznie wspomaganej prokreacji, wydaje się łatwiejsze do zaakceptowania. Jednocześnie należy zauważyć, że nie eliminuje to możliwości przypisania ojcostwa dawcy gamet w przypadku dawstwa partnerskiego na podstawie domniemania $\mathrm{z}$ art. 85 k.r.o. w brzmieniu nadanym art. 91 pkt 5 Ustawy o leczeniu niepłodności ${ }^{27}$.

Niezależnie od przedstawionych rozbieżności należy podzielić krytyczne uwagi wobec obecnego uregulowania. K. Bączyk-Rozwadowska zwraca uwage na naruszenie w ten sposób interesów majątkowych męża lub partnera biorczyni w zakresie obowiązku alimentacyjnego wobec dziecka, jak również interesu osobistego przejawiającego się $\mathrm{w}$ wolności prokreacyjnej i prawie do decydowania o sposobie wykorzystania zdolności płodzenia ${ }^{28}$.

\section{PODSUMOWANIE}

Zgoda mężczyzny na zabieg medycznie wspomaganej prokreacji jest ważnym elementem omawianej procedury. $Z$ jednej strony stanowi warunek konieczny jej przeprowadzenia, z drugiej - wiąże się ze skutkami rodzinnoprawnymi w zakresie ustalenia ojcostwa mężczyzny, który ją wyraził. Mimo tak doniosłych konsekwencji omawianego zagadnienia, sposób jego prawnego uregulowania nie jest wolny od wad, które mogą zostać uznane za przejaw dyskryminacji mężczyzny jako uczestnika procedury medycznie wspomaganej prokreacji. Chodzi tu zarówno o brak równości praw kobiety i mężczyzny, którzy uczestniczą w procedurze

25 J. Haberko, Ustawa..., s. 151.

26 M. Domański, op. cit., s. 984.

27 Zwraca na to uwagę K. Bączyk-Rozwadowska, op. cit., s. 688, przyp. 256.

28 Ibidem, s. 686. 
medycznie wspomaganego rozrodu, jak i o brak jednolitego uregulowania uprawnień małżonka biorczyni oraz mężczyzny, który pozostaje z biorczynią w stałym pożyciu potwierdzonym zgodnym oświadczeniem. Obowiązująca regulacja prawa skutkuje również różnicami w legislacyjnym statusie mężczyzny będącego mężem lub partnerem biorczyni w zależności od tego czy są oni uczestnikami procedury medycznie wspomaganej prokreacji przeprowadzanej w ramach dawstwa partnerskiego bądź innego niż partnerskie. W obszarze o tak doniosłych skutkach prawnych nie tylko dla samego mężczyzny uczestniczącego w procedurze medycznie wspomaganej prokreacji, ale również dla innych podmiotów (takich jak dziecko poczęte w wyniku jej zastosowania oraz biorczyni), należałoby oczekiwać bardziej precyzyjnego uregulowania prawnego, które uwzględniałoby takie czynniki, jak długotrwałość procedur medycznych, możliwość zmiany planów prokreacyjnych uczestników w czasie ich trwania oraz wpływ złożonych oświadczeń na ukształtowanie stosunków filiacyjnych.

\section{CONSENT TO CONDUCT A MEDICALLY ASSISTED PROCREATION PROCEDURE AND MAN'S FREEDOM OF REPRODUCTION IN THE LIGHT OF THE ACT ON TREATING INFERTILITY}

\section{Summary}

The article analyses the issue of consent of a man who is a participant in medically assisted procreation to its implementation and its family and legal consequences as well as the consequences of failure to grant or recall it in the context of his reproductive freedom. The applicable legal regulation raises interpretation doubts regarding the equal status of participants in the medically assisted procreation procedure and the legal position of a man, depending on whether he is the spouse or partner of the recipient, and whether the couple undergoes the discussed procedure as part of partner donation or non-partner donation.

Keywords: partner, donation, consent, procreation, reproductive freedom

\section{BIBLIOGRAFIA}

Bączyk-Rozwadowska K., Prokreacja medycznie wspomagana. Studium z dziedziny prawa, Toruń 2018.

Domański M., [w:] Kodeks rodzinny i opiekuńczy. Komentarz. Przepisy wprowadzające KRO, t. 5, red. K. Osajda, Warszawa 2017.

Haberko J., Kilka uwag na temat zgody na zabieg medyczny wyrażonej przez matżonka w trybie art. 68 Kodeksu Rodzinnego i Opiekuńczego, „Ruch Prawniczy, Ekonomiczny i Socjologiczny" 2010, z. 1.

Haberko J., Ustawa o leczeniu nieptodności. Komentarz, Warszawa 2016.

Łączkowska M., Czy istnieje prawo do „posiadania” dziecka?, [w:] Prawne, medyczne, psychologiczne aspekty wspomaganej prokreacji, red. J. Haberko, M. Łączkowska, Poznań 2005. 
Michałowska K., Niemajątkowe wartości życia rodzinnego w polskim prawie cywilnym, Warszawa 2017.

Oszkinis B., Wolność prokreacyjna - zarys problematyki, „Prawo i Medycyna” 2013, nr 1-2.

Robertson A.J., Procreative liberty in the era of genomics, „American Journal of Law and Medicine" 2003, nr 29.

Soniewska M., Selekcja genetyczna w prokreacji medycznie wspomaganej. Etyczne i prawne kryteria, Warszawa 2018. 